УДК 655.024

\title{
МЕТОДИ ВИГОТОВЛЕННЯ АЛЮМІНІЄВИХ ПІГМЕНТІВ ДЛЯ ВИКОРИСТАННЯ В ПОЛІГРАФІЧНІЙ ПРОМИСЛОВОСТІ
}

() А. С. Морозов, к.т.н., доцент, Є. Г. Сухіна, О. В. Гуща, Д. В. Безкоровайна, студентки, нТУу «КПІ», Київ, Україна

\section{В статье проанализированы существующие методы получения алюминиевых пигментов для печатных процессов.}

In the article being methods of production aluminums pigments for the printing processes has been analyzed.

\section{Постановка проблеми}

Різноманітні оздоблювальні ефекти для оформлення поліграфічної продукції користуються надзвичайною популярністю. Одним із способів створення даних ефектів є металізовані фарби. Провідні компанії-виробники цих фарб постійно працюють над стабілізацією оптичних, фізико-хімічних та інших властивостей пігментів, від яких залежить якість готового фарбового шару. Фарби володіють відмінними накочувальними властивостями, добре полімеризуються на всіх типах підкладок, включаючи слабовсотувальні і невсотувальні матеріали. Завдяки збалансованим властивостям металізовані фарби забезпечують високу стабільність друку як на низько-, так і на високошвидкісних друкарських машинах останнього покоління.

\section{Аналіз попередніх досліджень}

У межах поліграфічного матеріалознавства недостатньо висвітлені питання про особливості отримання алюмінієвих пігментів для друкарських процесів [1-3]. Існують деякі дані про технології виготовлення таких частинок відомих фірм - Eckart-Werke, BendaLutz-Werke, Schlenk (Німеччина), Wolstenholme (Англія) та інші, але цілісне уявлення про саму технологічну структуру їх виготовлення відсутнє, обсяг інформації дуже обмежений (мабуть, з комерційних міркувань) і вона має здебільшого рекламний характер [4-5]. Тому питання, що розглядається в даній роботі, спрямоване на необхідність узагальнення існуючих даних з виготовлення металевих пігментів та подальшого їх застосування у фарбах, і є вельми актуальним.

\section{Мета роботи}

Метою даної роботи є більш глибокий аналіз технологічних аспектів одержання алюмінієвих пігментів для подальшого прогнозування перспектив застосування такої продукції на українському поліграфічному ринку, враховуючи їх удосконалені властивості. 


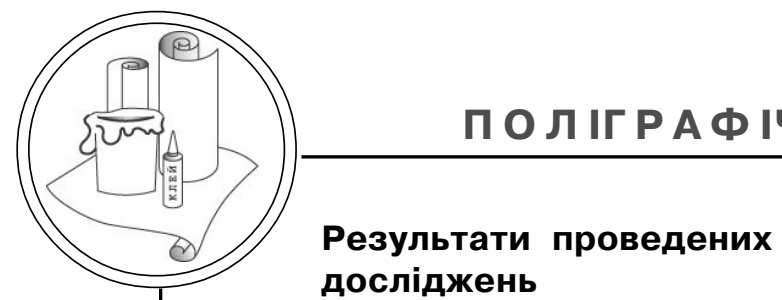

Всі алюмінієві пігменти можна різнити за їх розміщенням у фарбовому шарі після його висихання (рис. 1), а саме на спливаючі та неспливаючі.

Спливаючі пігменти характеризуються високою відображаючою здатністю покриття з ефектом «срібного дзеркала», але розподіл частинок у фарбовому шарі робить покриття досить чутливим до різноманітних механічних пошкоджень. 3 метою підвищення міцністних характеристик готового фарбового шару рекомендується використовувати захисне лакове покриття.

Неспливаючі пігменти характеризуються меншою відображаючою здатністю, тому ефект, що створюється, має назву «металеве срібло». Орієнтація металевих частинок по всьому об'єму здебільшого хаотична, що спричиняе надзвичайну стійкість до стирання та значно зменшує процеси окиснення.

Полімерна композиція, що містить металеві пігменти, відноситься до класу псевдодисперснозміцнених матеріалів і має

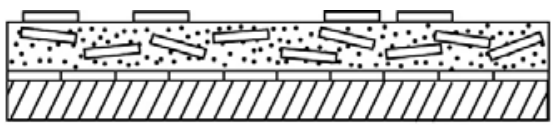
Звичайні спливаючі пігменти

a a

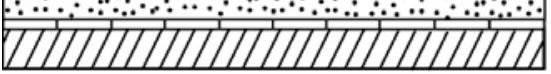
Неспливаючі ВМП обмежену товщину порядку 1,5...2 мкм [6]. Характеризується така композиція особливою дислокаційною структурою, яка має дуже гарні бар'єрні властивості проти росту тріщин i, таким чином, підвищуе також міцністні характеристики. Наприклад, вони можуть визначатися при склерометричних випробуваннях шляхом нанесення подряпин на металізовану поверхню. При добрій адгезії частинки деформуються разом з об'єктом, не відриваючись від нього [7].

На сьогоднішній день існуе три методи виготовлення алюмінієвих пігментів. Це спосіб вакуумної металізації, продуктом якого $€$ вакуумні металізовані пігменти (ВМП), метод порошкової металургії, який містить операції механічного подрібнення i розпилення рідкого розплаву металу, подрібнення стружкових відходів алюмінієвих сплавів за допомогою прокатного стану.

Найсучасніше виробництво алюмінієвих пігментів спрямоване на виготовлення частинок ультракласу методом вакуумної металізації (рис. 2). Ця технологія забезпечила появу фарб «рідкого металу» (Mirasheen) i
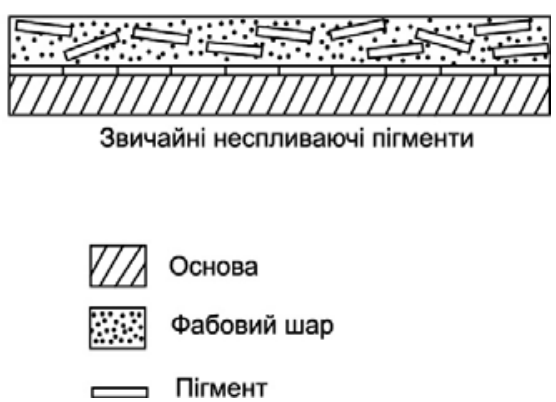

Рис. 1. Розподіл пігментів у фарбовому шарі металізованих фарб 


\section{Обладнання та матеріали}

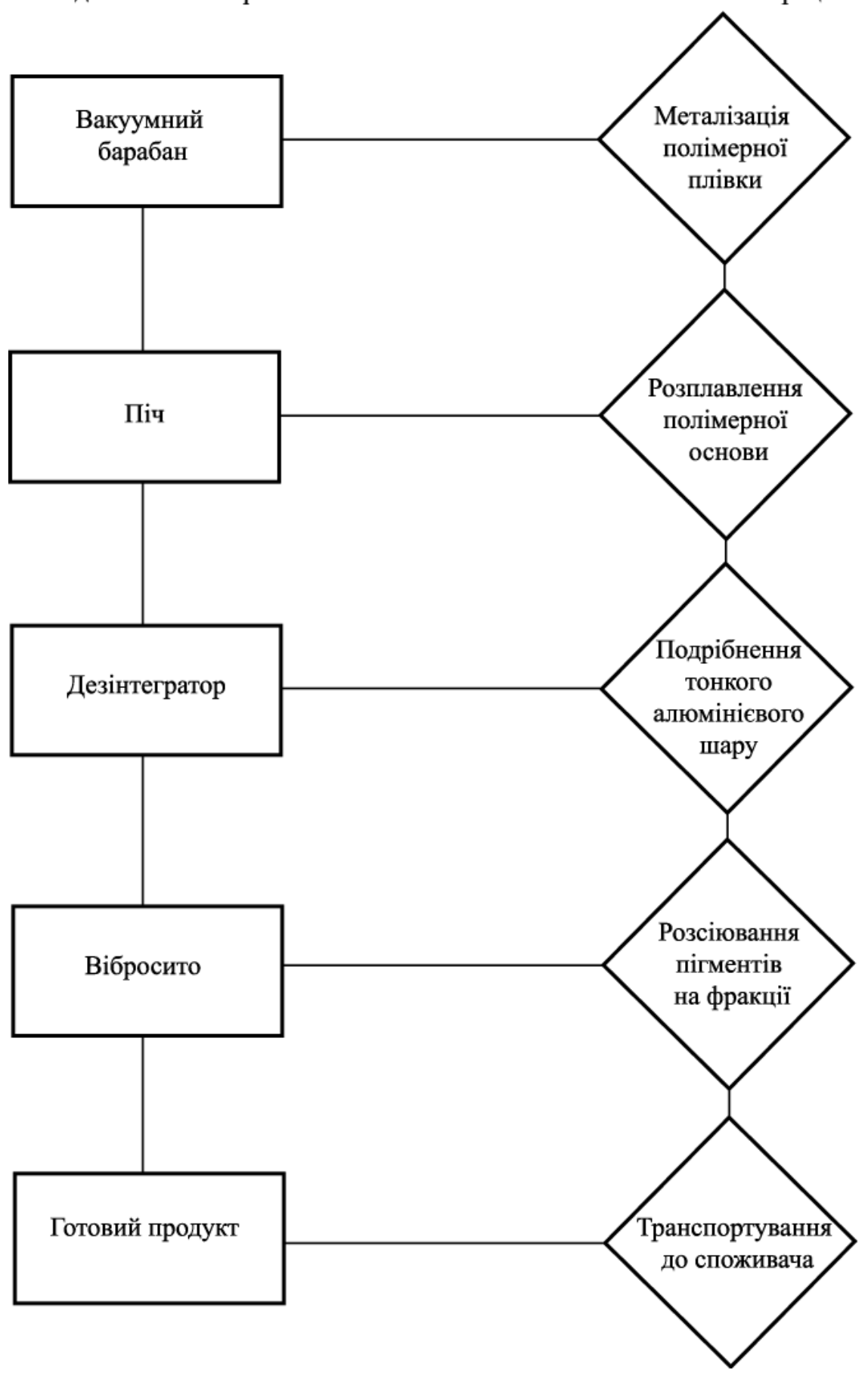

Рис. 2. Технологічна схема виготовлення алюмінієвих ВМП

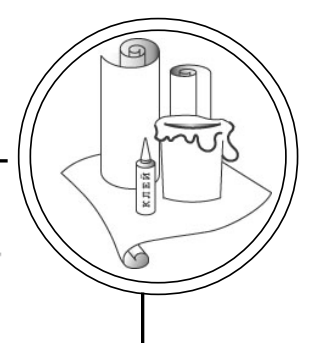




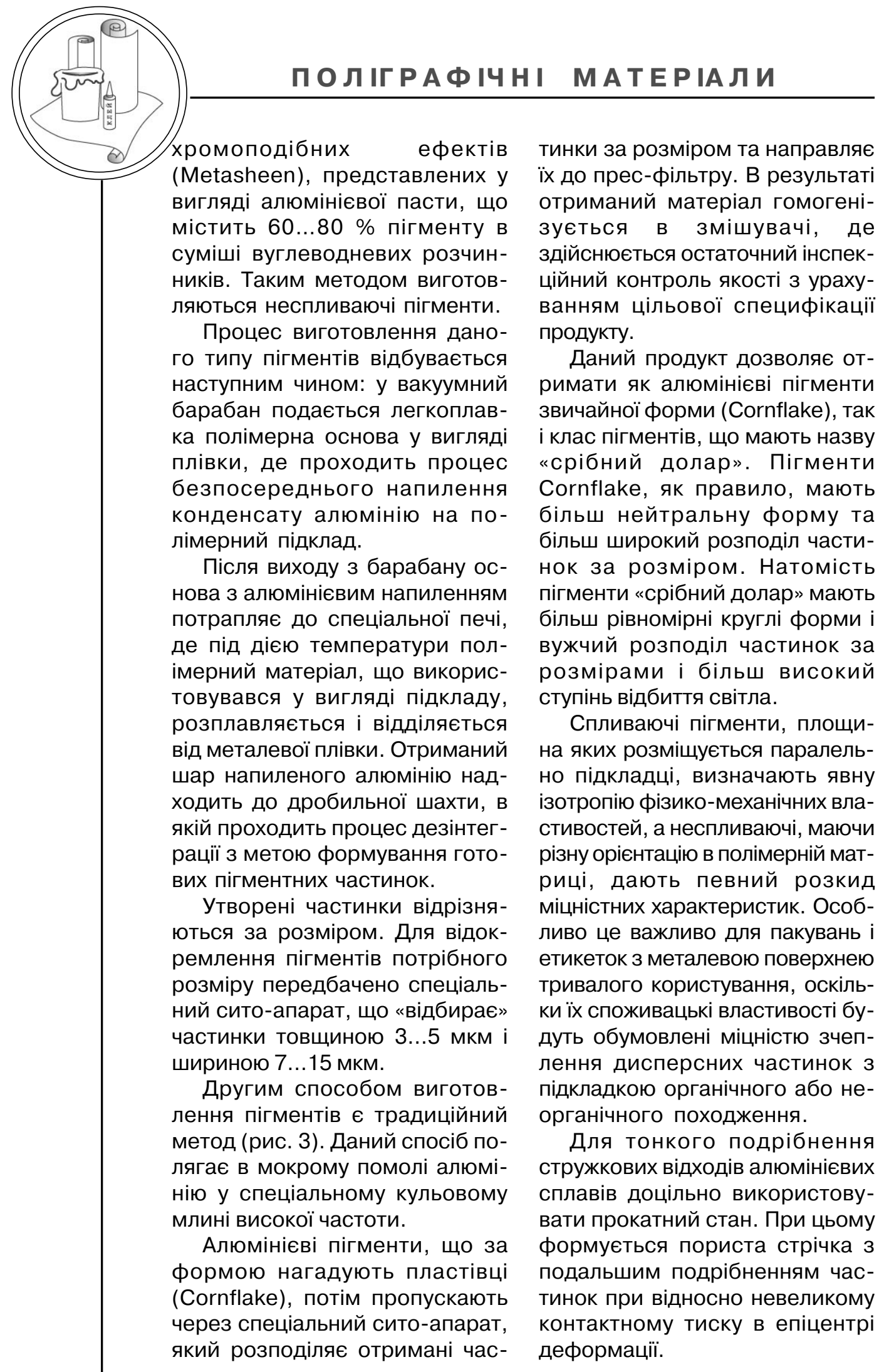




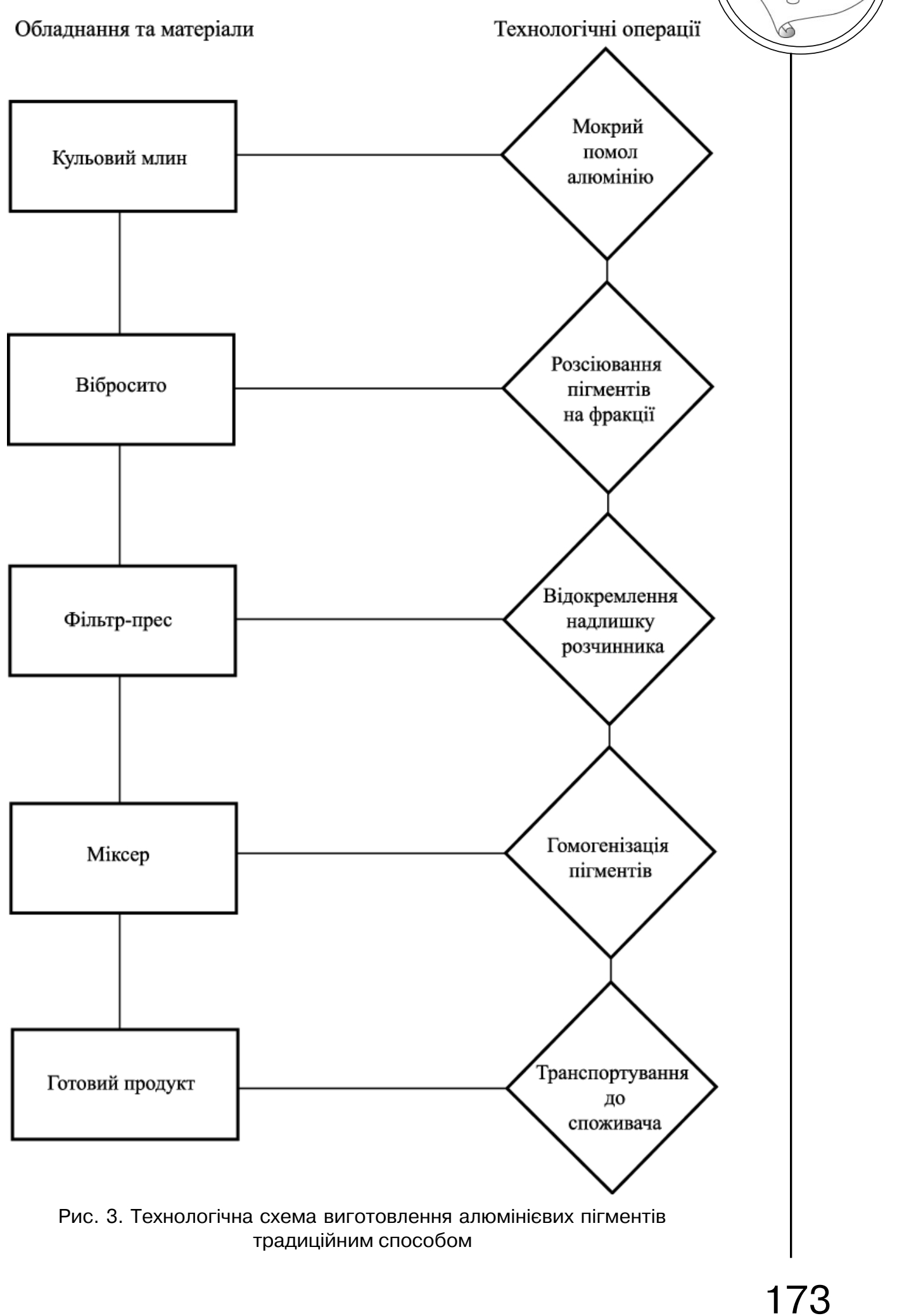




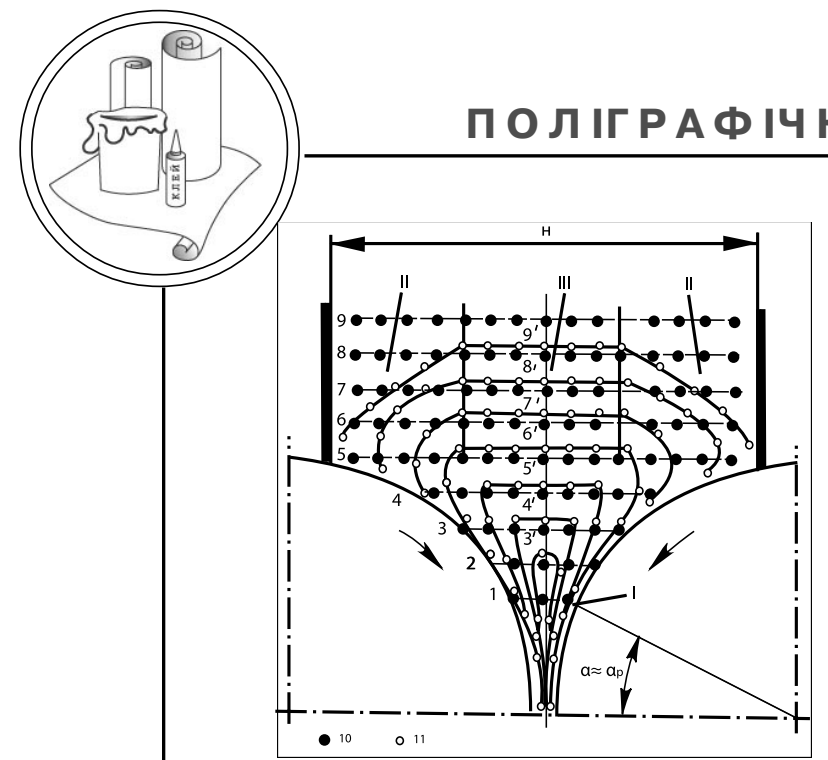

Рис. 4. Діаграми пересування стружкових частинок в бункері прокатного комбайну при вертикальній прокатці: 1-9 - горизонти укладки стружкових частинок; 10 - вихідний стан частинок; 11 - стан частинок після повороту валків

Специфіка прокатки стружкових частинок полягає у тому, що: по-перше, з них формується стрічка невеликої міцності, подруге, вона легко руйнується в звичайному атриторі. Багаторазовість таких операцій з вищевказаною послідовністю дає можливість отримувати порошок дуже дрібних фракцій 10...30 мкм з мінімальним окисненням.

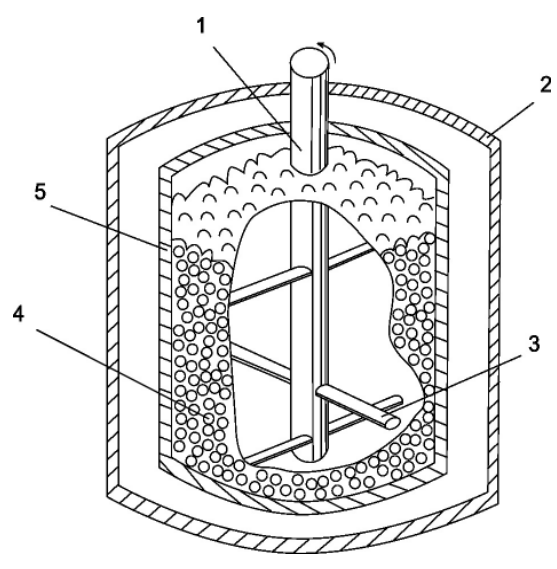

Рис. 5. Вертикальний атритор: 1 - вал; 2 - стінки водоохолоджуючого кожуха; 3 - лопасті подрібнювача; 4 - розмольні тіла; 5 - внутрішня стінка

На рис. 4 та на рис. 5 подана технологічна схема переробки стружкових частинок алюмінію.

Безумовно, існує суттєве обмеження використання порошку із стружкових відходів для металізованого друку через доволі значний розмір пігментних частинок. Електроерозійний метод (ЕЕМ) дозволяе значно зменшити розміри готових частинок. В його

Витратні матеріали на основі алюмінію

\begin{tabular}{|c|c|}
\hline \multicolumn{2}{|c|}{$\begin{array}{c}\text { Діапазон існуючих паст, пудр, порошків, гранул на основі алюмінію } \\
\text { для металізованих фарб }\end{array}$} \\
\hline Пасти & Пудри, гранули \\
\hline Лускоподібні пасти & Лускоподібні пудри \\
\hline Нелускоподібні пасти & $\begin{array}{c}\text { Лускоподібні пудри, не утворюючі пил } \\
\text { Depual }\end{array}$ \\
\hline $\begin{array}{l}\text { Нелускоподібні пасти для одержання } \\
\text { металевого блиску }\end{array}$ & $\begin{array}{c}\text { Нелускоподібні пудри, не утворюючі пил } \\
\text { Depual }\end{array}$ \\
\hline $\begin{array}{c}\text { Пасти для одержання дзеркального ефекту } \\
\text { Spendal }\end{array}$ & Нелускоподібні пудри Hydrostab \\
\hline $\begin{array}{c}\text { Лускоподібні пасти Hydrostab для систем } \\
\text { фарб на водній основі }\end{array}$ & Пігменти у формі гранул Compal \\
\hline Нелускоподібні пасти Hydrostab & \\
\hline
\end{tabular}


основі - подрібнення металу імпульсними електричними розрядами в рідині або в газових середовищах.

Теоретично при відповідних параметрах розрядів методом EEM $€$ можливість отримати найбільш дрібні частинки аж до атомарного рівня. Спочатку, при використанні даного методу, стружкові відходи можна попередньо зруйнувати на прокатному стані, а потім утворені елементні металеві стрічки піддати EEM. Після такої обробки маємо порошок 3 дуже високим вмістом кисню на поверхні, який потім бажано піддати процесу відновлення.

Саме алюмінієві пігменти мають найширше розповсюдження на ринку поліграфічних композицій (табл.) і на їх основі виготовляється ціла низка витратних напівфабрикатів.

\section{Висновки}

Зараз основною задачею виробників металізованих фарб є збереження стійкістних характеристик алюмінієвих пігментів як в умовах зберігання, так і у процесі безпосереднього друкування без застосування допоміжних паст, пудр або гранул для універсальних фарб УФ-закріплення. Саме такими є фарби 3 алюмінієвими ВМП, єдиним недоліком яких $є$ дорога ресурсна база, що позначається на ціні готової фарби. 3 даної точки зору виготовлення пігментів традиційним способом $€$ більш привабливим, так як у даному випадку в якості вихідної сировини можливе використання різноманітних стружкових відходів, що значно зменшує витрати на виробництво.

1. Алюминиевые пигменты [Електронний ресурс]. - Режим доступу: URL: http://www.pigments.witec.com.ua/catalogue/metal-pigment/. 2. Металлические пигменты [Електронний ресурс]. - Режим доступу : URL : http:// www/afaya/ru/pigm/metal-al.shtml. 3. Применение алюминиевых порошков [Електронний ресурс]. - Режим доступу : URL : http://www.rodonit.com.ua/ katalog-produkcii/aluminievye - poroshki-pudru-pusty. 4. Рамонов Д. Особенности работы с металлизированными красками / Д. Рамонов // Мир этикетки. - 2007. - № 4. - С. 37-46. 5. Металлизированные пигменты для этикеточной печати. [Електронний ресурс]. - Режим доступу : URL : $\mathrm{http} / /$ www.printpage.ru/poleznaia-informatsia/statii-poligrafia/12htm. 6. Киричок П. О. Особливості застосування металізованих фарбових плівок поліграфічного призначення / П. О. Киричок, Т. А. Роїк, А. С. Морозов, К. І. Савченко // Наукові вісті. - 2008. - № 4. - С. 94-98. 7. Киричок П. О. Металеві порошки в поліграфічних технологіях як чинник оптимізації споживацьких властивостей етикеточних і паковальних виробів / П. О. Киричок, Т. А. Роїк, А. С. Морозов, К. І. Савченко // Технологія і техніка друкарства. - 2007. № 3-4. -- С. 137-143. 8. Кругообіг відходів: від стружки до металевих пігментів у поліграфічній фарбі на упаковці та їх повторне використання: материалы XXX юбил. междунар. конф. «Композиционные материалы в промышленности». - Ялта, Крым, 7-11 июня, 2010. - С. 247-250.

$$
\text { Рецензент - О. В. Зоренко, к.Т.н., }
$$
доцент, НТУУ «КП।» 